\title{
Partner Odaklı Dua Ölçeği Türkçe Formu Geçerlik ve Güvenirlik Çalışması
}

\author{
Ahmet AKIN ${ }^{1}$ \\ Abdullah YALNIZ²
}

Öz: Bu araştırmanın amacı, Partner Odaklı Dua Ölçeğini Türkçe’ye uyarlamak ve ölçeğin geçerlik ve güvenirlik analizlerini yapmaktır. Araştırma 165 k1z ve 139 erkek olmak üzere toplam 304 üniversite öğrencisi üzerinde yürütülmüşsür. Doğrulayıcı faktör analizinde tek boyutlu modelin iyi uyum verdiği görülmüştür $\left(x^{2}=0.22, \mathrm{sd}=1, \mathrm{RMSEA}=0.000, \mathrm{NFI}=1.00\right.$, $\mathrm{CFI}=1.00, \mathrm{IFI}=1.00, \mathrm{RFI}=1.00, \mathrm{GFI}=1.00, \mathrm{SRMR}=.0027)$. Ölçeğin madde toplam korelasyon katsayıları “.74 ile .92” arasında sıralanmaktadır. Ölçeğin iç tutarlık katsayısı “.93” olarak hesaplanmıştır. Çalışma sonucunda ulaşılan bulgular, Partner Odaklı Dua Ölçeğinin Türkçe formunun geçerli ve güvenilir bir ölçme aracı olduğunu göstermektedir.

Anahtar sözcükler: Partner odaklı dua, Geçerlik, Güvenirlik, Doğrulayıcı faktör analizi

\section{GİRIŞ}

Dua, Allah'a yönelik minnettarlık duyma, teşekkür etme ve O’ndan isteklerde bulunma davranışının geleneksel formudur (Lambert,

1 Doç. Dr., Sakarya Üniversitesi Psikolojik Danışmanlık ve Rehberlik Bölümü Sakarya. aakin@sakarya.edu.tr

2 Uzm. Psk. Dan., Sakarya Üniversitesi Eğitim Bilimleri Bölümü Sakarya. abdullahyalniz@gmail.com 
Fincham, Graham, \& Beach, 2009). Dua ve romantik ilişkiler, kişiler arası ilişkiler kavramları, psikoloji alanında çok fazla birlikte ele alınmayan konulardı ve bunların daha çok teolojinin ilgi alanına girdiği düşünülmektedir. Ancak dini ritüeller ve manevi deneyimler, çiftler arasındaki ilişkinin inşasında rol oynayabilmekte ya da var olan ilişki açısından biçimlendirici bir işlev görebilmektedir. Konuyla ilgili özellikle yurtdışında çalışmalar yapılmış; dini aktivitelerin ve dindarlığın, pozitif aile iklimi oluşmasında anlamlı bir etkiye sahip olduğuna ilişkin araştırma sonuçları elde edilmiştir (Brodsky, 2000; Mahoney, Pargament, Murray-Swank, \& Murray-Swank, 1999).

Dua; çiftler arasında oluşan çatışmaları tatlıya bağlar; evlilik gibi uzun süreli bir beraberlikte aşk, şefkat ve anlayış gibi var olması gereken temel değerleri güçlendirir. Dua çiftleri, birbirlerine olan bağlıllılarının derinliği üzerinde düşünmeye yönlendirir; ilişkilerinin kıymetini bilmelerini sağlar. Bu şekilde yapılan dua, çiftlerin evliliklerinin sağlamlığını ve sürekliliğini temin eder; eşlerin birbirlerine olan adanmışlıklarını hafızalarında canlı tutmaları noktasında önemli bir görev üstlenir (Beach, Fincham, Hurt, McNair, \& Stanley, 2008). Çünkü dua, bireyin gerçekleştirmeye niyet ettiği davranışı, Allah’ın etkileme potansiyelini vurgulamaktadır (Fincham \& Beach, 2014).

Çiftler arasında tartışma olduğunda bu iki birey içinde verimsizlik doğurmaktadır. Birçok terapist, böyle zamanda çiftlerin rahatlaması için aktiviteler önermektedir. Sözlü dua etmek, dinleyecek insanlar olmad1ğında, kişiyi destekleyecek bir alternatif unsur olmaktadır (Beach ve diğerleri, 2008). Duanın özünde sahip olunandan çok, eksiklik duyulan şeylere odaklanmak ve onları istemek vardır (Lambert ve diğerleri, 2009).

Romantik ilişkilerin, manevi inançlarla desteklenmesi çiftler arasındaki uyumu artırabilmektedir. Manevi inançlara örnek olarak, evliliğin ölümsüz doğasına olan inanç, kutsal kitapla ilgili dini aktiviteler ve dua verilebilir (Lambert \& Dollahite, 2006). Eşlerin birbirlerini merkeze alarak dua etmeleri, aralarındaki sevgiyi artırarak aile bağlarını kuvvetlendirebilmektedir. Bunun yanı sıra eşi için dua eden bireyin; diğerkâmlık, fedakârlık ve hoşgörülü olma gibi kişisel özellikleri 
gelişebilmektedir. Dua etmek, kişinin istediği davranışları yapma konusundaki hedeflerini etkileyebilir ve böylece çiftin ilişkisini güçlendirmek veya zayıflatmak noktasında etkide bulunabilir (Fincham ve diğerleri, 2010). Çünkü dua, evliliğe zarar verecek yanlış davranışların etkisini azaltmada, karmaşı problemlerin çözümünde ve yıkıcı hedefleri etkisizleştirmede önemli bir etkiye sahiptir (Beach ve diğerleri, 2008).

Eşe yönelik dua etme davranışı, bireyin eşine olan sevgisini yoğunlaştırabilmekte ve eşler arasındaki uyumu artırabilmektedir. Konuyla ilgili olarak yapılan bir çalışmada; dua gibi dini aktivitelerin Katolik çiftlere, aile geçimsizlikleri olduğunda öfkelerini yönetmede yardımcı olduğu saptanmıştır (Marsh \& Dallos, 2001). Bir diğer araştırmada, duanın çiftlere empatik davranış kazandırdığ 1 ve kendini geliştirme isteğini artırdığı bulunmuştur. Aynı çalışmada dua etme davranışının, eşler arası uyumu artırma ve problem çözme becerilerini geliştirme gibi konularda çiftlere katkı sağladığı bulgusuna ulaşılmıştır (Butler, Stout, \& Gardner, 2002).

Dua, olumlu duygulara ve davranışlara olan etkisi nedeniyle ilişki memnuniyeti ile bağlantılı olabilir. Örneğin eş için dua etmek, ilişkideki pozitif duyguları ve olumlu davranışları artırabilmektedir (Fincham, Beach, Lambert, Stillman, \& Braithwaite, 2008). Yapılan bir nitel araştırmada katılımcı bazı çiftler, duanın öfkeyi gidermesinden ve açık iletişime olanak tanımasından söz etmektedirler. Örneğin ev hanımı olan bir anne, geceleri yaptıkları dua ibadetinin; birbirlerine yönelmiş öfkelerini ortadan kaldırmalarına nasıl yardımcı olduğunu anlatmıştır. Bu gibi eşler için dua, polemiklerin yaşandığı zamanlardaki öfke ifadelerini azaltmak ve iletişimi güçlendirerek aile içindeki, geçimsizliği azaltmak gibi işlevler görmektedir (Lambert \& Dollahite, 2006).

Romantik ilişkilerde duanın rolünü ortaya koymak amacıyla yapılan bir başka araştırmada, bu hedefe ulaşmak için 3 aşamalı bir çalışma yürütülmüştür. 1. aşamada eş için dua etme davranışının, aldatmanın azalmasıyla (aldatmaktan daha fazla kaçınmayla) ilişkisi olup olmadığg araştırılmıştır. 2. aşamada ise, dua edilerek yürütülen bir ilişkiye duanın etkisini test eden bir işleyiş incelenmiştir. 3. aşamada objektif 
gözlemciler tarafından değerlendirme yapılmasının, öz-bildirime dayalı açıklamalardan daha sağlıklı sonuçlar vereceği düşünülmüştür. Bu bağlamda gözlemciler tarafından, eşler arasındaki bağlılık düzeyine duanın etkisi incelenmiştir. Katılımcılar 2 gruba ayrılmış ve 1. gruptakiler diğer gruptan farklı olarak, eşlerine 4 hafta boyunca dua etmişlerdir. $\mathrm{Bu}$ çalışma sonucunda eşe dua etmenin, eşler arasındaki ve romantik ilişkilerdeki bağlılığı artırdığı bulgusuna ulaşılmıştır (Fincham ve diğerleri, 2010).

Ülkemizde dua kavramıyla romantik ve yakın ilişkiler kavramının birlikte çalışıldığı araştırma sayısı son derece sınırlıdır. Bu kavramlar ve konu, teolojinin ilgi alanına girdiği düşünülerek psikoloji sahasındaki araştırmacılar tarafından yoğun olarak çalışılmamıştır. Ancak yurtd1şında bu konuyla ilgili çalışmalar, daha çok psikoloji ve aile danışmanlığı alanında çalışan araştırmacılar tarafından ele alınmaktadır. Bu durum, bu araştırmanın yürütülmesi için motivasyon kaynağı olmuştur. Bu çalışmanın amacı Fincham, Lambert ve Beach (2010) tarafından geliştirilen Partner Odaklı Dua Ölçeği'nin Türkçe formunun geçerlik ve güvenirliğini incelemektir.

\section{YÖNTEM}

\subsection{Araştırma Grubu}

Ölçeğin Türkçe formunun geçerlik ve güvenirlik analizleri, 165 ’ i kız ve 139'u erkek toplam 304 üniversite öğrencisinden edilen veriler üzerinde yürütülmüştür. Ölçeğin orijinali yakın ilişki yaşayan üniversite öğrenciler üzerinde geliştirildiği için, Türkçe uyarlama çalışmasında katılımcılar yakın ve romantik bir ilişki yaşayan üniversite öğrencilerinden seçilmiştir.

\section{2. Ölçme Araçları}

2.2.1 Partner Odaklı Dua Ölçeği (Fincham, Lambert, \& Beach (2010): Tek boyutlu olan ve 4 maddeden oluşan ölçek 5'li likert tipi bir 
derecelendirmeye (1 Asla - 5 Her zaman) sahiptir. Ölçeğin orjinalinin Cronbach alfa iç tutarlılık güvenirlik katsayısı .96 olarak saptanmıştır. Uyum geçerliği çalışmasında partner odaklı dua ile ilişki doyumu arasinda pozitif $(r=.13)$, partner odaklı dua ile sadakatsizlik arasında negatif ilişki $(r=-.17)$ bulunmuştur.

\section{3 İşlem}

İlk olarak, ölçeği uyarlamak için elektronik posta aracılığıyla izin alınmıştır. Öncelikle ölçek 3 öğretim üyesi tarafından önce Türkçeye çevrilmiş, daha sonra tekrar İngilizceye çevrilerek, çeviri ile orijinal form arasındaki tutarlılık incelenmiş ve denemelik Türkçe form elde edilmiştir. Daha sonra ölçeğin denemelik Türkçe formu, 2 öğretim üyesi tarafından incelenmiştir. Birden fazla anlam içeren veya açı olmayan ifadeler tespit edilmiştir. Son aşamada ise Türkçe form eğitim bilimleri anabilim dalında görev yapan 2 öğretim üyesi tarafından tartışılarak düzeltmeler yapılmış ve ölçeğe son şekli verilmiştir. Partner Odaklı Dua Ölçeğinnin yapı geçerliğinin incelenmesi amacıyla doğrulayıcı faktör analizi (DFA) uygulanmıştır. Partner Odaklı Dua Ölçeğỉnin güvenirliği Cronbach alfa iç tutarlık yöntemiyle, madde analizi ise düzeltilmiş madde-toplam korelasyonuyla incelenmiştir. Geçerlik ve güvenirlik analizleri için SPSS 20.0 ve LISREL8.54 (Joreskog \& Sorbom, 1996) programları kullanılmıştır.

\section{BULGULAR}

\subsection{Madde Analizi ve Güvenirlik}

Partner Odaklı Dua Ölçeği’nin maddelerinin ayırt etme gücünü belirlemek amacıyla madde analizi yapılmıştır. Yapılan analiz sonucunda, ölçeğin düzeltilmiş madde toplam korelasyon katsayılarının .74 ile .92 arasında sıralandığı görülmüştür. Ölçeğin iç tutarlılık güvenirlik katsayıs1 .93 olarak bulunmuştur. Bulgular Tablo 1'de sunulmuştur. 
Tablo 1: PODÖ Düzeltilmiş Madde Toplam Korelasyon Katsayısı

\begin{tabular}{cc}
\hline Madde No & $\boldsymbol{r j} \boldsymbol{x}$ \\
\hline 1 & .82 \\
2 & .92 \\
3 & .88 \\
4 & .74 \\
\hline
\end{tabular}

\subsection{Yapı Geçerliği}

Partner Odaklı Dua Ölçeğinin yapı geçerliği için ölçeğin orijinal formunda bulunan faktörlerin doğrulanması amacıyla DFA uygulanmıştır. Ölçeğin yapı geçerliği için uygulanan doğrulayıcı faktör analizinde 4 maddeden oluşan, tek boyutlu ve faktör yükleri .78 ile .95 arasında sıralanan Partner Odaklı Dua Ölçeği’nin iyi uyum verdiği görülmüştür $\left(x^{2}=0.22, \mathrm{sd}=1, \mathrm{RMSEA}=0.000, \mathrm{NFI}=1.00, \mathrm{CFI}=1.00, \mathrm{IFI}=1.00\right.$, $\mathrm{RFI}=1.00, \mathrm{GFI}=1.00, \mathrm{SRMR}=.0027)$. Ancak, 1.-2. maddeler arasinda ikili hata kovaryansı tanımlanmıştır. Doğrulayıcı faktör analizine ait faktör yükleri Şekil l'de sunulmuştur:

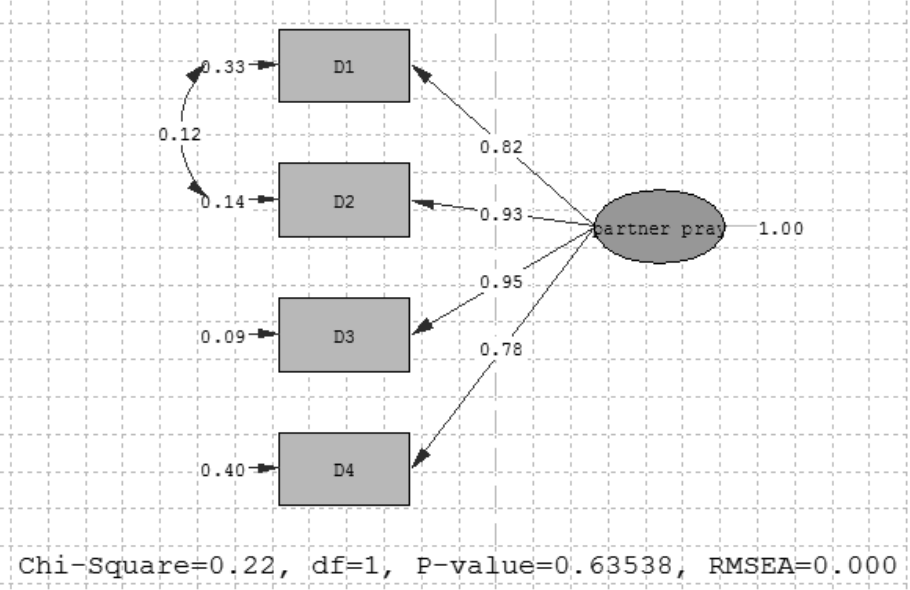

Şekil 1: Yakın İlişkilerde Minnettarlığı İfade Etme Ölçeğine İlişkin Path Diyagramı ve Faktör Yükleri 


\section{YORUM/TARTIŞMA}

Bu çalışmada, Fincham, Lambert ve Beach (2010) tarafından geliştirilen Partner Odaklı Dua Ölçeğinnin Türkçeye uyarlanması ve Türkçe formun geçerlik ve güvenirliğinin incelenmesi amaçlanmıştır. Ölçeğin yapı geçerliği DFA ile incelenmiştir. DFA için uyum indeksi sınırları göz önüne alındığında, modelin iyi uyum verdiği ve ölçeğin orijinal faktör yapısının Türkçe formun faktör yapısıyla uyuştuğu görülmektedir. Doğrulayıcı faktör analizi ile model-veri uyumuna ilişkin hesaplanan istatistiklerden en sık kullanılanları Ki-kare $\left(x^{2}\right), \mathrm{x}^{2} / \mathrm{sd}$, RMSEA, RMR, GFI ve AGFI'dir. Hesaplanan $x^{2} / \mathrm{df}$ oranının 5 'ten küçük olması, GFI ve AGFI değerlerinin .90'dan yüksek olması model-veri uyumunu göstermektedir (Marsh \& Hocevar, 1988). Bununla birlikte, GFI'nin .85'ten, AGFI'nin .80 'den büyük çıkması, RMSEA değerlerinin .10 'dan düşük çıkması, model veri uyumu için kabul edilebilir alt sınırlar olarak görülmektedir (Marsh, Balla, \& McDonald, 1988).

Partner Odaklı Dua Ölçeğinnin güvenirlik katsayılarının yüksek bulunması, güvenirliğin yeterli düzeyde olduğunu göstermektedir. Araştırmalarda kullanılabilecek ölçme araçları için öngörülen güvenirlik düzeyinin .70 olduğu (Tezbaşaran, 1996) dikkate alınırsa, PODÖ'nün güvenirliğini belirlemeye yönelik olarak elde edilen bulgular ölçeğin yeterli düzeyde güvenilir olduğunu ortaya koymuştur. Madde analizi sonucunda ölçeğin madde-toplam korelasyon katsayılarının .30 ölçütünü karşıladığ 1 görülmüştür. Madde-toplam korelasyon katsayılarının yorumlanmasında .30 ve daha yüksek olan maddelerin, bireyleri ölçülen özellik bakımından iyi derecede ayırt ettiği göz önüne alındığında (Büyüköztürk, 2004), madde toplam korelasyon katsayılarının yüksek düzeyde olduğu görülmektedir.

Partner Odaklı Dua Ölçeği'nin geçerlik ve güvenirlik çalışmalarından elde edilen tüm bulgular, bu ölçeğin bireylerin partner odaklı dua etme düzeyini belirlemek amaciyla yeterli düzeyde geçerlik ve güvenirliğe sahip olduğunu ortaya koymuştur.

Yakın ilişkilerin ve özellikle de evlilik yaşamının ülkemizde giderek daha problemli bir hal almaya devam ediyor olması; aile ve evlilik 
danışmanlığı gibi alanlarda materyalist ve fiziksel çözümlerin yanı sıra manevi temelleri içeren bir psikolojik danışma modelinin gelişimini zorunlu hale getirmektedir. Bu nedenle psikolojik danışmanlar, aile psikologları ve din psikolojisi gibi alanlardaki uzmanlar tarafından bu ölçme aracının geniş bir kullanım alanı bulacağı düşünülmektedir. Duanın psikolojik ve manevi etkisi dikkate alındığında aile içi yakın ilişkilerde bireylerin birbirlerine bu tarzda bir başa çıkma ve ilişki kurma tarzı benimsemeye yönlendirilmelerinde ve bu tür bir eksikliğin saptanarak giderilmeye çalışılmasında bu araç yararlı olacaktır.

\section{5. ÖNERILLER}

Partner Odaklı Dua Ölçeğinnin geçerlik ve güvenirlik çalışmalarından elde edilen bulgular çerçevesinde bazı önerilerde bulunulabilir. Ölçeğin geçerlik ve güvenirlik çalışmalarının yürütüldügü araştırma grubu yakın ve romantik ilişkisi olan ve bir partneri olan üniversite öğrencilerinden oluşmaktadır. Dolayısıyla ölçeğin evli bireyler üzerinde geçerlik güvenirlik çalışmalarının yapılması önemlidir. Ayrıca ölçeğin dilsel eşdeğerliğinin incelenmesine de ihtiyaç duyulmaktadır. İleride yapılacak çalışmalarda, test tekrar test yöntemiyle ölçeğin güvenilirliğinin belirlenmesi önerilebilir. Bunun yanı sıra ölçeğin uyum geçerliğini belirlemek amacıyla partner odaklı dua ile diğer ilişkili kavramlar arasındaki bağlantılar; geçerliği ve güvenirliği kanıtlanmış başka ölçekler aracılığyla incelenebilir.

\section{Kaynakça}

Beach, S. R. H., Fincham, F. D., Hurt, T., McNair, L. M., \& Stanley, S. M. (2008). Prayer and marital intervention: A conceptual framework. Journal of Social and Clinical Psychology, 27, 693-710.

Brodsky, A. E. (2000). The role of religion in the lives of resilient, Urban, African American, single mothers. Journal of Community Psychology, 28, 199-219. 
Butler, M. H., Stout, J. A., \& Gardner, B. C. (2002). Prayer as a conflict resolution ritual: clinical implications of religious couples' report of relationship softening, healing perspective, and change responsibility. American Journal of Family Therapy, 30, 19-37.

Büyüköztürk, Ş. (2004). Veri analizi el kitabı. Ankara: Pegem A Yayıncılık.

Fincham, F. D., Beach, S. R. H., Lambert, N., Stillman, T. \& Braithwaite, S. (2008). Spiritual behaviors and relationship satisfaction: A critical analysis of the role of prayer. Journal of Social and Clinical Psychology, 27(4), 362-388.

Fincham, F. D., Lambert, N. M., \& Beach, S. R. H. (2010). Faith and unfaithfulness: Can praying for your partner reduce infidelity? Journal of Personality and Social Psychology, 99(4), 649-659.

Fincham, F. D., \& Beach, S. R. H. (2014). I say a little prayer for you: Praying for partner increases commitment in romantic relationships. Journal of Family Psychology, 28(5), 587-593.

Joreskog, K. G., \& Sorbom, D. (1996). LISREL 8 Reference Guide, Lincolnwood IL: Scientific Software International.

Lambert, N. M., \& Dollahite, D. C. (2006). How religiosity helps couples prevent, resolve and overcome marital conflict. Family Relations, 55, 439-449.

Lambert, N. M., Fincham, F. D., Graham, S. M., \& Beach, S. R. H. (2009). Can prayer increase gratitude? Psychology of Religion and Spirituality, 1(3), 139-149.

Mahoney, A., Pargament, K. I., Murray-Swank, A., \& Murray-Swank, N. (2003). Religion and the sanctification of family relationships. Review of Religious Research, 44, 220-236.

Marsh, H. W., Balla, J. R., \& McDonald, R. P. (1988). Goodness-of-fit indexes in confirmatory factor analysis: The effect of sample size. Psychological Bulletin, 103, 391-410.

Marsh, R. D., \& Dallos, R. (2001). Roman catholic couples: Wrath and religion. Family Process, 40, 343-460. 
Marsh, H. W., \& Hocevar, D. (1988). A new more powerful approach to multitrait-multimethod analyses: Application of second-order confirmatory factor analysis. Journal of Applied Psychology, 73, 107-117.

Tezbaşaran. A. A. (1996). Likert tipi ölçek geliştirme kılavuzu. Ankara: Türk Psikologlar Derneği Yayınları.

$* * * * * * * * * * * *$

Abstract: -Turkish Version of Partner-Focused Prayer Scale (PFPS): The Study of Validity and Reliability-The aim of this research is to examine the validity and reliability of the Turkish version of the Partner-Focused Prayer Scale (PFPS). Participants were 304 undergraduate students (165 females and 134 males). Results of confirmatory factor analysis demonstrated that this scale yielded one factor, as original form $(x=$ $0.22, \mathrm{df}=1, \mathrm{RMSEA}=0.000, \mathrm{NFI}=1.00, \mathrm{CFI}=1.00, \mathrm{IFI}=1.00, \mathrm{RFI}=$ $1.00, \mathrm{GFI}=1.00, \mathrm{SRMR}=.0027)$. Corrected item-total correlations ranged from ".74 to .92 ". The internal consistency coefficient of the scale was “.93”. Thus Partner-Focused Prayer Measure can be used as a valid and reliable instrument in education.

Key words: Partner-focused prayer, Validity, Reliability, Confirmatory factor analysis

\section{Summary}

There have been many studies on partner focused prayer in English and other languages but there are few studies in Turkish. In this case appears to be strong need to have a reliable and valid measurement tool to measure Turkish individual's levels of partner focused prayer in relationships. Partner-Focused Prayer Scale (PFPS; Fincham, Lambert, \& Beach, 2010) may be considered as a helpful tool to fill in this need but there is no study indicating the tool's level of reliability and validity in Turkey. Thus the aim of this research is to translate the Partner-Focused Prayer Scale (PFPS) to Turkish and to examine its psychometric properties. 
Participants were 304 university students. Primarily the PFPS was translated into Turkish by three academicians. The Turkish form was back-translated into English and the consistency between the Turkish and English forms was examined. Than Turkish form has been reviewed by two academicians. Finally they discussed the Turkish form and along with some corrections the scale was prepared for validity and reliability analyses. Partner-Focused Prayer Scale (PFPS) were used as data collecting method in the research. The scale contains 4 items (e.g., "I pray that good things will happen for my partner.") with each item rated on a 5-point Likert-type scale. In this study, confirmatory factor analysis (CFA) was executed to confirm the original scale's structure in Turkish culture. As reliability analysis Cronbach alpha internal consistency coefficient and the item-total correlations were calculated. Data were analyzed using LISREL 8.54 and SPSS 20.0 package programs. CFA provide empirical-based evidence for determining whether the Turkish version of PFPS would yield or construct a similar structure to the original version of PFPS.

The results of confirmatory factor analysis demonstrated that the 4 items loaded on one factor and that the factor structure was harmonized with the factor structure of the original scale. The results of confirmatory factor analysis indicated that the model was well fit $\left(x^{2}=0.22\right.$, $\mathrm{df}=1, \mathrm{RMSEA}=0.000, \mathrm{NFI}=1.00, \mathrm{CFI}=1.00, \mathrm{IFI}=1.00, \mathrm{RFI}=1.00, \mathrm{GFI}=$ 1.00 , SRMR $=.0027)$. The Cronbach alpha internal consistency reliability coefficient of the scale was .93. The corrected item-total correlations of Partner-Focused Prayer Measure (PFPM) ranged from .74 to .92. According to these values it can be said that the structural model of Partner-Focused Prayer Scale (PFPS) which consists of one factor was well fit to the Turkish culture.

Overall findings demonstrated that this scale had high validity and reliability scores and that it may be used as a valid and reliable instrument in order to assess the partner-focused prayer of individuals. Nevertheless, further studies that will use Partner-Focused Prayer Scale are important for its measurement force. As a result, it can be said that PFPS 
Toplum

is a valid and reliable instrument to measure the levels of partner-focused prayer of Turkish individuals. In addition, studies that examine the relations between the partner-focused prayer and variables such as faith activities at home, religious commitment or perception of God find answers for many questions. 